\title{
Transparansi Anggaran Pendapatan dan Belanja Daerah di Era Pandemi Covid-19: Peran Sistem Informasi Pemerintahan Daerah
}

\author{
I Gusti Ayu Yuli Kartika ${ }^{1^{*}}$ \\ A. A. N. Eddy Supriyadinata Gorda ${ }^{2}$ \\ 1,2Fakultas Ekonomi dan Bisnis Universitas Pendidikan Nasional, Indonesia \\ *Correspondences : ogekseraya@gmail.com
}

\begin{abstract}
ABSTRAK
Transparansi dalam Anggaran Pendapatan dan Belanja Daerah (APBD) merupakan salah satu perwujudan Good Governance. Penelitian ini bertujuan untuk menguji pengaruh aksesibilitas, sistem pengendalian internal, dan penyusunan anggaran berbasis kinerja terhadap transparansi APBD dengan penerapan Sistem Informasi Pemerintahan Daerah (SIPD) sebagai variabel intervening. Penelitian ini dilakukan di Badan Pengelola Keuangan dan Aset Daerah Provinsi Bali (BPKAD). Populasi penelitian adalah seluruh pegawai negeri sipil di BPKAD dan teknik penyamplingan yang digunakan adalah sampling jenuh. Structural equation model digunakan sebagai alat analisis data. Hasil penelitian menunjukan Sistem Informasi Pemerintahan Daerah (SIPD) memediasi secara positif pengaruh aksesibilitas, sistem pengendalian internal, dan penyusunan anggaran berbasis kinerja terhadap transparansi APBD.
\end{abstract}

Kata Kunci: Aksesibilitas; Sistem Pengendalian Internal; Anggaran Berbasis Kinerja; Transparansi.

\section{Transparency of Regional Revenue and Expenditure Budgets in the Era of the COVID-19 Pandemic: The Role of Regional Government Information System}

\footnotetext{
ABSTRACT

Transparency in the Regional Revenue and Expenditure Budget $(A P B D)$ is one manifestation of Good Governance. This study aims to examine the effect of accessibility, internal control system, and performance-based budgeting on APBD transparency with the application of the Regional Government Information System (SIPD) as an intervening variable. This research was conducted at the Bali Province Regional Financial and Asset Management Agency (BPKAD). The research population is all civil servants in BPKAD and the sampling technique used is saturated sampling. Structural equation model is used as a data analysis tool. The results showed that the Regional Government Information System (SIPD) positively mediated the influence of accessibility, internal control systems, and performancebased budgeting on APBD transparency.

Keywords: Accessibility; Internal Control System; Performance Based Budgeting; Transparency.
}

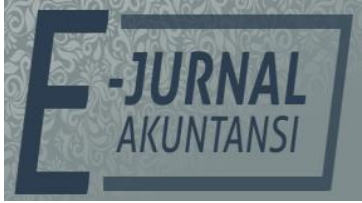

e-ISSN 2302-8556

Vol. 32 No. 1

Denpasar, Januari 2022 Hal. 62-75

DOI:

10.24843/EJA.2022.v32.i01.p05

PENGUTIPAN:

Kartika, I G. A. Y., Gorda, A.

A. N. E. S. (2022).

Transparansi Anggaran

Pendapatan dan Belanja

Daerah di Era Pandemi

COVID-19: Peran Sistem Informasi Pemerintahan

Daerah. E-Jurnal Akuntansi, 32(1), 62-75

RIWAYAT ARTIKEL:

Artikel Masuk:

27 September 2021

Artikel Diterima: 6 Januari 2022

Artikel dapat diakses : https://ojs.unud.ac.id/index.php/Akuntansi/index 


\section{PENDAHULUAN}

Pelaksanaan penerapan administrasi publik melewati berbagai macam pergantian paradigma, dimulai dari model klasik atau disebut administrasi negara lama hinggga good governance yang mulai dikenal sejak tahun 1990 hingga sekarang. World Bank menyatakan governance dijabarkan cara kekuasaan negara digunakan dalam mengelola sumber daya ekonomi dan sosial untuk pembangunan masyarakat (Wasistiono, 2003). Sehingga, Bank Dunia menempatkan economic governance dengan misi perbaikan tata kelola ekonomi yang mendukung administrasi publik, salah satunya adalah penggunaan anggaran yang tepat dan diketahui publik sebagai salah satu wujud dari good governance. Penerapan prinsip good governance, yaitu transparansi mempengaruhi kualitas laporan keuangan (Vita et al., 2018). Good governance dapat dicapai setelah transparansi administrasi telah terwujud dalam setiap proses administrasi publik (Vilone, 2020).

Salah satu alat untuk mewujudkan good governance pada penyelenggaraan administrasi public khususnya pelaporan keuangan adalah penyusunan anggaran yang terbuka dan dapat diakses oleh publik baik pada tingkat pusat maupun tingkat daerah. Anggaran diperlukan dalam pengelolaan sumber daya yang dimiliki pemerintah dengan baik untuk mencapai kinerja yang diharapkan oleh masyarakat dan menciptakan akuntabilitas publik (Mulyadi et al., 2018). Pemerintah memiliki kewajiban untuk mempertanggungjawabkan penggunaan anggaran kepada masyarakat. Hal tersebut didukung dengan adanya UndangUndang Republik Indonesia Nomor 14 Tahun 2008 tentang keterbukaan informasi publik sebagai landasan legal formal dari prinsip transparansi, khususnya pada pasal 9(c) mengenai keterbukaan informasi laporan keuangan. Pemerintah Daerah berkewajiban memberikan informasi keuangan secara berkesinambungan, sehingga masyarakat dapat diberikan kesempatan penuh untuk megetahui besaran anggaran yang ditetapkan dan bagaimana posisi keuangan daerah dalam setiap periode pelaporan (Aminah et al., 2020; Ciplet et al., 2018), .

Pemerintah melalui organisasi perangkat daerah bekerjasama dalam mewujudkan keterbukaan informasi bagi publik (Wismaningtyas \& Kurniasih, 2021). Keterbukaan informasi yang berkaitan dengan anggaran disampaikan dalam laman web masing-masing instansi. Informasi mengenai keuangan dan asset yang erat kaitannya dengan anggaran dikelola oleh Badan Pengelola Keuangan dan Aset Daerah (BPKAD). Badan Pengelola Keuangan dan Aset Daerah melaksanakan prinsip keterbukaan pengelolaan keuangan daerah sesuai amanat Undang-Undang Republik Indonesia Nomor 14 Tahun 2008 Tentang Keterbukaan Informasi Publik dan Peraturan Pemerintah Republik Indonesia Nomor 12 Tahun 2019 Tentang Pengelolaan Keuangan Daerah.

Beberapa temuan di lapangan menunjukkan masih belum optimalnya pengungkapan informasi dalam pada laman web BPKAD. Salah satunya adalah pada BPKAD Provinsi Bali ditampilkan pada Tabel 1. Hasil temuan menunjukkan bahwa transparansi yang dilakukan oleh BPKAD Provinsi Bali dalam 5 (lima) tahun terakhir belum mencapai $100 \%$. Selain permasalahan tersebut, aksesibilitas dalam perolehan data pada website BPKAD juga masih sangat terbatas. Informasi yang disajikan cenderung bersifat umum sehingga belum mampu memberikan detail informasi penggunaan anggaran secara rinci. 
Tabel 1. Realisasi Upload Dokumen BPKAD Provinsi Bali (Periode 2016-2020)

\begin{tabular}{ccccc}
\hline No. & $\begin{array}{c}\text { Tahun } \\
\text { Anggaran }\end{array}$ & $\begin{array}{c}\text { Dokumen Wajib } \\
\text { Publikasi }\end{array}$ & $\begin{array}{c}\text { Dokumen } \\
\text { terpublikasi oleh } \\
\text { BPKAD }\end{array}$ & $\begin{array}{c}\text { Realisasi } \\
(\%)\end{array}$ \\
\hline 1. & 2016 & 17 & 0 & 0 \\
2. & 2017 & 17 & 0 & 0 \\
3. & 2018 & 17 & 3 & 17,64 \\
4. & 2019 & 17 & 12 & 70,58 \\
5. & 2020 & 17 & 11 & 64,70 \\
\hline
\end{tabular}

Sumber: Sekretariat BPKAD Provinsi Bali Diolah, 2021.

Tahun 2020 menjadi tahun yang sangat berbeda dengan tahun-tahun sebelumnya dikarenakan mewabahnya Corona Virus Disease 2019 (COVID-19). Tampak pada Tabel 1. terlihat publikasi dokumen pada tahun 2020 justru mengalami pemerosotan sebesar 5,88\% dari tahun sebelumnya. Hal tersebut disebabkan karena postur dan rincian APBD diseluruh wilayah megalami perubahan karena adanya pandemi tersebut. Perencanaan penganggaran beralih diprioritaskan untuk strategi penanganan seperti pada bidang kesehatan, pemulihan ekonomi nasional, bantuan sosial, dan dukungan industri. Masyarakat kini banyak yang tergiring untuk memiliki pandangan adanya manipulasi pada rumah sakit maupun pemerintah daerah hingga berbagai politisasi bantuan sosial. Transparansi anggaran diperlukan untuk mencegah adanya penyalahgunaan informasi atau hoaks. Menurut Kurniawati (2016) pemerintah daerah memang sudah mengunggah laporan keuangan pemerintah daerah pada website pemerintah tetapi sepenuhnya belum disosialisasikan kepada pihak eksternal dan terkendala saat ingin mengambil data pada website. Otoritas publik memiliki kewajiban untuk mempublikasikan secara online dokumen mereka, kemajuan ini juga mewakili kesulitan utama,karena implementasinya masih agak lambat (Avec \& Dandelot, 2018).

Sebagaimana telah diamanatkan dalam Peraturan Menteri Dalam Negeri Republik Indonesia Nomor 70 Tahun 2019 tentang Sistem Informasi Pemerintahan Daerah (SIPD), sistem ini merupakan sistem informasi yang terdiri dari sistem perencanaan pembangunan daerah dan sistem keuangan daerah, serta sistem pemerintahan daerah lainnya, termasuk sistem pembinaan dan pengawasan pemerintahan daerah. Permasalahan dalam penggunaan SIPD terdapat pada belum berjalannya sistem secara maksimal karena belum mampu mengakomodir tabel maupun lampiran yang dibutuhkan untuk APBD. Sistem ini juga sering mengalami perubahan atau dalam proses pembaruan. Wahyuni (2020) mengungkapkan permasalahan terhadap sistem informasi di daerah dapat membuat transparansi menjadi tidak optimal, sistem informasi akuntansi yang handal harus dimiliki pemerintah daerah agar dapat menghasilkan laporan keuangan yang handal, dapat dipercaya dan relevan. Maka dari itu, sistem informasi keuangan yang dikelola oleh pemerintah harus terbuka dan diketahui masyarakat.

Teknologi informasi dan komunikasi (TIK) telah mengubah cara berpikir dan melakukan proses organisasi, dengan demikian pekerjaan semakin supported, dilakukan atau diawasi oleh Information Systems (IS). Medina \& Rufín (2013) 
menjelaskan bahwa transparansi memiliki dampak langsung pada trust (Kepercayaan) dan dampak tidak langsung terhadap satisfaction (Kepuasan).

Pengendalian intern dalam suatu organisasi juga merupakan unsur yang menentukan keandalan laporan keuangan (Upabayu et al., 2015). Pengendalian intern yang teratur akan dapat meminimalkan kemungkinan terjadinya kesalahan atau kecurangan (Rashedi \& Dargahi, 2019). Semakin luas dan kompleksnya aktivitas perekonomian menuntut ketersediaan sistem pengendalian intern yang memadai (Maryanti, 2017). Adiwirya \& Sudana (2015) menemukan masih adanya penyimpangan anggaran berbasis kinerja di suatu instansi pemerintah. Kenyataan yang terjadi di BPKAD Provinsi Bali adalah penetapan APBD belum dilaksanakan secara tepat waktu. Kondisi lainnya yang terjadi adalah data dan informasi yang akurat serta memadai belum mendukung proses perumusan perencanaan, kebijakan, dan evaluasi. Latar belakang penelitian dan fenomena terkait transparansi menjadi acuan penelitian bahwa betapa pentingnya keterbukaan informasi pemerintah daerah dalam mengelola keuangan sehingga penelitian diarahkan untuk meneliti mengenai implementasi transparansi APBD di daerah dan faktor-faktor yang mempengaruhinya.

Good governance menjadi landasan dalam pengembangan penelitian ini. Good governance didasarkan dari definisi The World Bank yaitu terselenggaranya manajemen pembangunan yang sehat dan bertanggung jawab sesuai dengan prinsip demokrasi dan pasar yang efisien, penghindaran salah alokasi dana investasi dan pencegahan korupsi baik secara politik maupun administratif, penerapan disiplin anggaran dan penciptaan kerangka hukum dan politik untuk pertumbuhan bisnis. Pernyataan tersebut menggambarkan bahwa untuk mewujudkan tata pemerintahan yang baik, transparansi dalam penyelenggaraan APBD harus dilaksanakan sehingga mampu mewujudkan prinsip transparansi dan akuntabilitas publik serta tercapainya partisipasi masyarakat.

Wahyuni (2020) menyatakan laporan keuangan minimalnya harus dapat dimengerti dan tersedia bagi mereka yang tertarik dan mau berusaha untuk memahaminya. Aksesibilitas dengan sistem online sebagai alat komunikasi untuk berbagi informasi (Arceiz, 2019). Penelitian yang dilakukan oleh Rohaedi \& Sabaruddinsah (2013) menemukan bahwa aksesibilitas laporan keuangan daerah berpengaruh signifikan terhadap variabel penggunaan sistem informasi pengelolaan keuangan daerah. Sejalan dengan hal tersebut Kurniawati (2016) menyebutkan bahwa penyajian laporan keuangan daerah dan akses laporan keuangan daerah berdampak pada penerapan sistem informasi akuntansi keuangan daerah.

$\mathrm{H}_{1}$ : Aksesibilitas berpengaruh positif dan signifikan terhadap penggunaan SIPD di BPKAD Provinsi Bali.

Pengendalian intern organisasi merupakan salah satu faktor yang menentukan kualitas penerapan sistem informasi (Safkaur et al., 2019). Berdasarkan hasil penelitian yang dilakukan sebelumnya, salah satu faktor penyebab sistem informasi akuntansi yang tidak memadai dipengaruhi oleh lemahnya sumber daya manusia (Nurhayati et al., 2017). Pengendalian intern yang baik diharapkan mampu mereduksi kesalahan-kesalahan dari penerapan sistem serta memantau jalannya sistem dari suatu organisasi. Kontrol kelembagaan berpengaruh dalam pencapaian transparansi dan keterbukaan informasi (Aziz et 
al., 2020). Upabayu et al., (2015) menyatakan sistem pengendalian intern berpengaruh positif dan signifikan pada kualitas sistem informasi.

$\mathrm{H}_{2}$ : Sistem pengendalian intern berpengaruh positif dan signifikan terhadap penggunaan SIPD di BPKAD Provinsi Bali.

Anggaran berbasis kinerja adalah anggaran yang memperhatikan prioritas program dan kegiatan yang memerlukan aspek akuntabilitas dan transparansi dalam pelaksanaannya sehingga kualitas anggaran sesuai dengan maksud dan tujuan (Adiwirya \& Sudana, 2015). Penelitian oleh Anggayana et al., (2019) menyebutkan anggaran berbasis kinerja adalah suatu analisis yang dilakukan untuk mengetahui sejauh mana suatu organisasi telah menerapkan peraturan keuangan secara benar dan tepat dalam penyusunan laporan keuangan tahunannya, dan sistem informasi keuangan adalah informasi yang menggambarkan kondisi keuangan suatu organisasi yang digunakan sebagai sumber informasi keuangan evaluasi kinerja. Pengukuran kinerja yang baik memerlukan sistem informasi yang mampu menghasilkan informasi yang memadai untuk menilai pencapaian hasil kerja dari masing-masing unit kerja yang bertanggung jawab atas suatu kegiatan. Tingkat informasi dasar yang harus dikembangkan yaitu ekonomis, efektif dan efisien (Nanda \& Darwanis, 2016).

Sistem Informasi Pemerintahan Daerah (SIPD) dapat menjadi sarana untuk pengungkapan informasi dalam pengukuran kinerja. Pernyataan ini ditegaskan oleh Prabowo et al. (2017) yang menyatakan bahwa Undang-undang Keuangan Negara No. 17 Tahun 2003 mengatur tentang aturan umum proses penganggaran di Indonesia. Undang-undang tersebut mewajibkan pemerintah (pemerintah daerah dan pusat) tidak hanya menyiapkan anggaran tetapi juga mempublikasikannya. Sehingga, penggunaan SIPD berperan penting dalam proses penganggaran khususnya dalam hal publikasi informasi.

$\mathrm{H}_{3}$ : Sistem penyusunan anggaran berbasis kinerja berpengaruh positif dan signifikan terhadap penggunaan SIPD di BPKAD Provinsi Bali.

Transparansi secara luas dianggap penting untuk meminta pertanggungjawaban negara dan membangun kepercayaan (Gupta et al., 2017). Implementasi prinsip-prinsip tata kelola yang baik, yaitu transparansi, mempengaruhi kualitas laporan keuangan (Fazny \& Setiyawati, 2019). Sistem informasi dalam hal ini SIPD jika berjalan dengan optimal diharapkan mampu menciptakan transparansi dengan lebih mudah (Aminah et al., 2020). Untary (2015) mengungkapkan dengan kemajuan teknologi saat ini, pelaporan keuangan daerah telah memanfaatkan sistem informasi di mana dengan penerapannya diharapkan akan meningkatkan keterbukaan terhadap masyarakat luas. Implementasi sistem informasi akuntansi memiliki hubungan positif terhadap keandalan laporan keuangan (Al-Dmour, 2018).

$\mathrm{H}_{4}$ : Penggunaan SIPD berpengaruh positif dan signifikan terhadap transparasi anggaran di BPKAD Provinsi Bali.

Wahyuni (2020) menemukan bahwa aksesibilitas laporan keuangan daerah secara parsial berpengaruh terhadap transparansi pengelolaan keuangan daerah. Menurut Kurniawati (2016) Aksesibilitas yang efektif tergantung kepada akses publik terhadap sistem informasi laporan keuangan yang dapat dibaca dan dipahami. Pernyataan tersebut juga diungkapkan oleh Hehanussa (2015) yang menyebutkan bahwa aksesibilitas dalam mendapatkan laporan keuangan daerah 
melalui sistem informasi memiliki pengaruh yang positif dan signifikan terhadap transparansi dan akuntabilitas.

$\mathrm{H}_{5}$ Penggunaan SIPD mampu memediasi pengaruh aksesibilitas terhadap transparasi anggaran di BPKAD Provinsi Bali.

Sari (2017) mengemukakan bahwa semakin baik sistem pengendalian internal suatu lembaga pemerintah maka semakin transparan laporan keuangan yang dibuat. Hal ini karena pengenalan sistem pengendalian internal yang baik menjamin keandalan laporan keuangan dan data keuangan. Penelitian yang dilakukan oleh Untary (2015) menyatakan kompetensi dan kemampuan sumber daya manusia mampu mentransformasikan data keuangan menjadi sistem informasi berkualitas yang akan di publikasikan dan akan dibutuhkan masyarakat. Upabayu et al. (2015) menyebutkan bahwa untuk menghasilkan laporan keuangan yang berkualitas melalui sistem informasi diperlukan kapasitas sumber daya manusia yang mumpuni untuk mengoperasikan sistem dengan baik dengan kata lain sistem pengendalian internal memberikan pengaruh yang signifikan terhadap efektivitas sistem informasi akuntansi. Menurut Fuadah \& Setiyawati (2020) transparansi diperlukan untuk memberikan informasi keuangan yang telah disusun dengan basis kinerja secara terbuka dan jujur kepada masyarakat agar di ketahui dan dapat diakses dengan mudah secara menyeluruh, dengan memanfaatkan teknologi informasi dalam komputer dan pengendalian internal dalam pengelolaan keuangan meningkatkan kualitas laporan keuangan, baik dari sisi persiapan maupun akurat dalam sebuah laporan keuangan.

$\mathrm{H}_{6:}$ Penggunaan SIPD mampu memediasi pengaruh sistem pengendalian intern terhadap transparasi anggaran di BPKAD Provinsi Bali.

Aryani \& Muliati (2020) mengutarakan sistem informasi akuntansi keuangan daerah diharapkan dapat memberikan dukungan yang kuat melalui tercapainya penyusunan anggaran berbasis kinerja pemerintah daerah yang baik dengan tujuan akhir memberikan pelayanan terhadap publik dalam bentuk transparansi. Upabayu et al. (2015) menyampaikan bahwa instansi pemerintah saat ini perlu meningkatkan kualitas kinerja keuangan untuk mengikuti perkembangan akuntansi karena pengguna sistem informasi menuntut akuntabilitas dan transparansi yang lebih besar di lembaga pemerintah.

$\mathrm{H}_{7:}$ Penggunaan SIPD mampu memediasi pengaruh penyusunan anggaran berbasis kinerja terhadap transparasi anggaran di BPKAD Provinsi Bali.

\section{METODE PENELITIAN}

Unsur yang menunjang urusan pada pemerintahan dalam ranah keuangan yang menjadi kekuasaan daerah adalah Badan Pengelola Keuangan dan Aset Daerah (BPKAD) Provinsi Bali sehingga penelitian dilakukan di BPKAD Provinsi Bali. Populasi penelitian mencakup seluruh PNS di BPKAD Provinsi Bali. Sampel penelitian ditentukan dengan teknik non probability sampling. Kuesioner digunakan dalam memperoleh data pada penelitian ini. Kuesioner didistribusikan secara langsung kepada PNS di BPKAD Provinsi Bali. Sebanyak 116 kuesioner yang kembali digunakan sebagai data penelitian.

Terdapat tiga jenis variabel dalam penelitian ini. aksesibilitas $\left(X_{1}\right)$, sistem pengendalian intern $\left(X_{2}\right)$, dan penyusunan anggaran berbasis kinerja $\left(X_{3}\right)$ merupakan variabel independen sedangkan transparansi APBD merupakan 
variabel dependen (Y) dan variabel pemediasi yaitu SIPD (M). Aksesibilitas dioperasionalkan dengan menggunakan beberapa indikator yang dijelaskan oleh Rohaedi \& Sabaruddinsah (2013) yakni waktu, akurat, relevan, dan lengkap. Sistem pengendalian intern dioperasionalkan dengan menggunakan beberapa indikator yang dijelaskan oleh Maryanti (2017) yakni manajemen resiko, informasi, komunikasi, dan aktivitas pengendalian. Penyusunan anggaran berbasis kinerja dioperasionalkan dengan menggunakan beberapa indikator yang dijelaskan pada Pasal 7 Peraturan Pemerintah Nomor 21 Tahun 2004 Tentang Penyusunan Rencana Kerja Dan Anggaran Kementerian Negara/Lembaga yakni indikator kinerja utama, indikator kinerja kegiatan, indikator keluaran, standar biaya, dan evaluasi kinerja. Sistem Informasi Pemerintahan Daerah dioperasionalkan dengan menggunakan beberapa indikator oleh Aminah et al., (2020) yakni Hardware, Software, Brainware, Database dan sistem database, serta Teknologi jaringan komunikasi. Teknik analisis data utama yang digunakan untuk menjawab rumusan masalah penelitian adalah structural equation model (SEM) dengan pendekalan OLS (ordinary least square) menggunakan bantuan aplikasi AMOS.

\section{HASIL DAN PEMBAHASAN}

Analisis statistik deskriptif, analisis ini dilakukan untuk mendeskripsikan variabel penelitian yang terdiri atas aksesibilitas $\left(\mathrm{X}_{1}\right)$, SPI $\left(\mathrm{X}_{2}\right)$, anggaran berbasis kinerja $\left(\mathrm{X}_{3}\right)$, penerapan SIPD $(\mathrm{M})$ serta transparansi $(\mathrm{Y})$ melalui nilai rata-rata penilaian responden terhadap variabel yang menunjukkan persepsi responden pada variabel penelitan, yang ditunjukkan oleh Tabel 2.

Tabel 2. Hasil Analisis Statistik Deskriptif

\begin{tabular}{lccccc}
\hline & $\mathrm{N}$ & Minimum & Maksimum & Rata-rata & Standar Deviasi \\
\hline $\mathrm{X}_{1}$ & 116 & 8,747 & 17,757 & 12,831 & 2,934 \\
$\mathrm{X}_{2}$ & 116 & 9,810 & 16,637 & 12,384 & 1,930 \\
$\mathrm{X}_{3}$ & 116 & 6,892 & 14,757 & 12,007 & 2,186 \\
$\mathrm{M}$ & 116 & 6,654 & 14,057 & 11,913 & 2,005 \\
$\mathrm{Y}$ & 116 & 6,293 & 13,913 & 8,046 & 1,410 \\
\hline
\end{tabular}

Sumber: Data Penelitian, 2021

Nilai mean aksesibilitas adalah 12,831, dibagi 4 (jumlah indikator aksesibilitas) memberikan nilai 3,21 (hasil pembulatan) dengan standar deviasi 2,934. Artinya rata-rata responden memberikan skor 3 untuk setiap poin penjelasan angket aksesibilitas. Hasil ini menunjukkan bahwa sistem informasi dan informasi BPKAD di Provinsi Bali relatif mudah diakses. Mean SPI adalah 12.384, yang jika dibagi 4 (jumlah indikator dalam SPI) memberikan nilai 3,09 (hasil pembulatan) dengan standar deviasi 1,930. Artinya rata-rata responden memberikan skor 3 untuk setiap item pernyataan angket SPI. Hasil ini menunjukkan bahwa SPI bekerja dengan baik di BPKAD Provinsi Bali.

Nilai mean untuk persiapan kru adalah 12,007, dibagi 5 (jumlah indikator dalam pelatihan $\mathrm{kru}$ ) memberikan nilai 2,40 (hasil pembulatan) dengan standar deviasi 2,186. Artinya rata-rata responden memberikan skor 2 untuk setiap item pada Kuesioner Kesiapan ABK. Hasil ini menunjukkan bahwa persiapan ABK di BPKAD Provinsi Bali belum berjalan dengan baik. Mean penggunaan SIPD adalah 11,913022, yang bila dibagi 5 (jumlah indikator saat menggunakan SIPD) 
memberikan nilai 2,38 (hasil pembulatan) dengan standar deviasi 2,005. Artinya rata-rata responden memberikan skor 2 untuk setiap item opini pada angket aplikasi SIPD. Hasil ini menunjukkan bahwa implementasi SIPD di BPKAD Provinsi Bali belum berjalan dengan baik.

Rata-rata (mean) nilai transparansi adalah 8,046 yang jika dibagi 4 (jumlah indikator transparansi) memberikan nilai 2.01 (hasil pembulatan) dengan standar deviasi 1,410. Artinya rata-rata responden memberikan skor 2 untuk setiap poin penjelasan angket transparansi. Hasil ini menunjukkan bahwa BPKAD Provinsi Bali kurang transparan dalam menyajikan informasi keuangannya. Setelah menganalisis model dengan analisis faktor konfirmatori, langkah selanjutnya adalah mengevaluasi kriteria kualitas untuk keseluruhan model. Hasil penelitian menunjukkan model sudah baik karena sebagian besar kriteria Godness of fit memenuhi syarat yaitu Cmin/df, GFI, AGFI dan NFI. Hasil estimasi masingmasing variabel eksogen dan variabel endogennya dapat dilanjutkan untuk menguji hipotesis penelitian yang disajikan pada Tabel 3.

Tabel 3. Rangkuman Hasil Estimasi

\begin{tabular}{lcccc}
\hline & Estimate & $\begin{array}{c}\text { Composite } \\
\text { Reliability }\end{array}$ & p-value & Keputusan \\
\hline Akses -> SIPD & 0,249 & 2,275 & 0,031 & Positif \\
SPI -> SIPD & 0,802 & 4,655 & 0,000 & Positif \\
P.ABK -> SIPD & 0,238 & 2,526 & 0,023 & Positif \\
SIPD -> Trans & 0,363 & 3,756 & 0,000 & $\begin{array}{c}\text { Positif } \\
\text { Akses -> SIPD -> Trans }\end{array}$ \\
SPI -> SIPD -> Trans & 0,187 & 2,184 & 0,044 & $\begin{array}{c}\text { Memediasi } \\
\text { secara Positif } \\
\text { P.ABK -> SIPD -> Trans }\end{array}$ \\
\end{tabular}

Sumber: Data diolah, 2021

Arah pengaruh variabel laten eksogen ditunjukan oleh nilai koefisien estimate setiap variabel apakah positif atau negatif. Signifikansi pengaruh variabel laten eksogen secara parsial tidak berpengaruh signifikan terhadap variabel laten endogen jika nilai composite reliability $<1,65$ dan nilai p-value $>0,1$ maka $\mathrm{H}_{0}$ diterima dan Ha ditolak. Sebaliknya, variabel laten eksogen secara parsial berpengaruh signifikan terhadap variabel laten endogen jika nilai composite

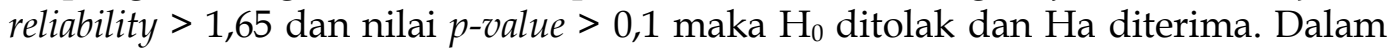
penelitian ini nilai alpha (rule of thumb) yang digunakan adalah sebesar 0,1 yakni pada taraf kepercayaan 90\% (Ferdinand, 2014:27).

Aksesibilitas memiliki nilai koefisien estimate positif terhadap SIPD sebesar 0,249 dan nilai composite reliability positif sebesar 2,275 > 1,65 dengan $p$-value 0,031 $<0,10$ (signifikan), sehingga $\mathrm{H}_{1}$ yang menyatakan aksesibilitas berpengaruh positif dan signifikan terhadap SIPD di BPKAD Provinsi Bali dapat diterima. Hasil tersebut bermakna jika aksesibilitas sistem yang dimiliki BPKAD semakin baik, cepat dan mudah, maka penerapan dan pengoperasian SIPD juga akan semakin baik. Hasil penelitian ini mendukung hasil yang ditemukan oleh Rohaedi \& Sabaruddinsah (2013) serta Kurniawati (2016) bahwa aksesibilitas berpengaruh positif dan signifikan terhadap SIPD. Aksesibilitas dalam memperoleh laporan keuangan APBD dapat diartikan sebagai kesederhanaan untuk memperoleh data 
laporan keuangan tersebut tanpa biaya, mudah, dan cepat. Laporan APBD atau keuangan daerah yang disajikan dalam Sistem Informasi Pemerintah Daerah (SIPD) dapat diakses dengan perangkat yang terhubung dengan koneksi internet. Dokumen APBD tersebut dapat kita lihat dan unduh jika kita dapat mengakses situs website SIPD. Kemudahan dalam membuka SIPD serta mengoperasikan SIPD.

Sistem pengendalian intern memiliki nilai koefisien estimate positif terhadap SIPD sebesar 0,802 dan nilai composite reliability positif sebesar 4,655 > 1,65 dengan $p$-value $0,000<0,10$ (signifikan), sehingga $\mathrm{H}_{2}$ yang menyatakan SPI berpengaruh positif dan signifikan terhadap SIPD di BPKAD Provinsi Bali dapat diterima. Hasil tersebut bermakna jika sistem pengendalian intern dilaksanakan dengan baik dan tepat, maka penerapan dan pengoperasian SIPD juga akan semakin baik pada BPKAD Provinsi Bali. Hasil penelitian ini mendukung hasil yang ditemukan oleh Upabayu et al., (2015), Tresyani (2019) dan Maryanti (2017) bahwa SPI berpengaruh positif dan signifikan terhadap SIPD. Sistem pengendalian intern terdiri atas kebijakan dan prosedur yang dirancang untuk memberikan manajemen kepastian yang layak bahwa organisasi telah mencapai tujuan dan. Pengendalian intern yang dilaksanakan dalam hal ini Sistem Informasi Pemerintahan Daerah, seperti kontrol oleh lingkungan organisasi terhadap keakuratan data yang masuk ke SIPD dan juga kontrol terhadap keamanan SIPD dapat mengoptimalkan penerapan SIPD tersebut.

Penyusunan anggaran berbasis kinerja memiliki nilai koefisien estimate positif terhadap SIPD sebesar 0,238 dan nilai composite reliability positif sebesar 2,526 $>1,65$ dengan $p$-value $0,023<0,10$ (signifikan), sehingga $\mathrm{H}_{3}$ yang menyatakan penyusunan ABK berpengaruh positif dan signifikan terhadap SIPD di BPKAD Provinsi Bali dapat diterima. Hasil tersebut bermakna jika penyusunan ABK dapat terlaksanan dengan baik seperti kualitas SDM pengoperasi memiliki kualitas yang baik, maka penerapan dan pengoperasian SIPD juga akan semakin baik pada BPKAD Provinsi Bali. Hasil penelitian ini mendukung hasil yang ditemukan oleh Anggayana, et.al., (2019) dan Aryani \& Muliati (2020) bahwa penyusunan ABK dapat menunjang pelaksanaan SIPD. Tujuan dari anggaran berbasis kinerja adalah mampu menerapkan perencanaan anggaran yang sesuai dengan kebutuhan daerah, tidak mementingkan salah satu kelompok, efektif serta efisien. Hal tersebut dapat dilaksanakan oleh sumber daya manusia yang kompeten dalam bidangnya. Penyusunan anggaran berbasis kinerja yang baik akan mendukung pemanfaatan dan juga mempengaruhi kualitas Sistem Informasi Pemerintahan Daerah.

SIPD memiliki nilai koefisien estimate positif terhadap transparansi sebesar 0,363 dan nilai composite reliability positif sebesar 3,756 > 1,65 dengan p-value 0,000 $<0,10$ (signifikan), sehingga $\mathrm{H}_{4}$ yang menyatakan SIPD berpengaruh positif dan signifikan terhadap transparansi anggaran di BPKAD Provinsi Bali dapat diterima. Hasil tersebut bermakna jika penerapan SIPD semakin optimal, maka penyampaian informasi daerah baik tentang keuangan, kepegawaian atau yang lainnya akan semakin cepat dan mudah pada BPKAD Provinsi Bali, sehingga transparansi akan terwujud. Hasil penelitian ini mendukung hasil yang ditemukan oleh Aminah et al., (2020) yang menyebutkan terdapat efek signifikan dan positif antara sistem informasi keuangan daerah terhadap transparansi. 
Tujuan penyajian laporan keuangan daerah adalah memberi informasi keuangan yang berguna untuk pembuatan keputusan ekonomi, sosial politik dan juga laporan akuntabilitas itu sendiri. Melalui SIPD atau sistem informasi transparansi tersebut dapat diakomodir, sehingga SIPD yang dijalankan dengan baik mengakibatkan proses penyampaian dokumen kepada masyarakat luas dapat tersampaikan dengan baik juga.

Aksesibilitas yang dimediasi oleh SIPD memiliki nilai koefisien estimate positif terhadap transparansi sebesar 0,187 dan nilai composite reliability positif sebesar 2,184 > 1,65 dengan p-value 0,044 < 0,10 (signifikan). Hasil tersebut menunjukkan SIPD merupakan partial mediation dalam penelitian ini, sehingga $\mathrm{H}_{5}$ yang menyatakan SIPD mampu memediasi pengaruh aksesibilitas terhadap transparasi anggaran di BPKAD Provinsi Bali dapat diterima. Temuan ini bermakna aksesibilitas yang baik akan mengoptimalkan penerapan SIPD, sehingga transparansi anggaran dapat terwujud di BPAKD Provinsi Bali. Hasil penelitian ini mendukung hasil yang ditemukan oleh Wahyuni (2020) dan Hehanussa (2015) bahwa aksesibilitas dalam mendapatkan laporan keuangan daerah melalui sistem informasi memiliki pengaruh yang positif dan signifikan terhadap transparansi. Aksesibilitas yang efektif tergantung kepada akses publik terhadap sistem informasi laporan keuangan yang dapat dibaca dan dipahami. Sistem informasi adalah suatu alat untuk menjembatani informasi kehadapan publik atau masyarakat demi terciptanya transparansi. Aksesibilitas yang tanggap dapat meningkatkan pengoperasian Sistem Informasi Pemerintahan Daerah yang baik, sehingga membuat transparansi berjalan dengan maksimal.

Sistem pengendalian intern yang dimediasi oleh SIPD memiliki nilai koefisien estimate positif terhadap transparansi sebesar 0,387 dan nilai composite reliability positif sebesar 4,112 > 1,65 dengan $p$-value 0,000 $<0,10$ (signifikan). Hasil tersebut menunjukkan SIPD merupakan partial mediation dalam penelitian ini, sehingga $\mathrm{H}_{6}$ yang menyatakan SIPD mampu memediasi pengaruh SPI terhadap transparasi anggaran di BPKAD Provinsi Bali dapat diterima. Temuan ini bermakna SPI yang baik dan tepat akan mengoptimalkan penerapan SIPD, sehingga transparansi anggaran dapat terwujud di BPAKD Provinsi Bali. Hasil penelitian ini mendukung hasil yang ditemukan oleh Untary (2015) dan Upabayu et al., (2015) bahwa kompetensi dari manajemen puncak dan pimpinan yang termasuk dalam SPI akan dapat mempengaruhi efiktivitas penerapan dari sistemtem informasi, sistem informasi yang efektif selanjutnya akan mempercepat terwujudnya transparansi. Pengendalian internal memiliki tujuan untuk menghasilkan output pekerjaan yang maksimal sesuai dengan tujuan organisasi, sehingga pengendalian internal merupakan faktor yang dapat membantu pelaksanaan transparansi. Semakin baik internal control system yang diterapkan pada suatu instansi pemerintah maka akan menghasilkan laporan keuangan yang lebih transparan, karena dengan menerapkan sistem pengendalian intern yang baik akan menjamin keandalan laporan keuangan dan data keuangan dengan pemanfaatan SIPD.

Penyusunan anggaran berbasis kinerja yang dimediasi oleh SIPD memiliki nilai koefisien estimate positif terhadap transparansi sebesar 0,144 dan nilai composite reliability positif sebesar 2,168 > 1,65 dengan p-value 0,046 0,10 (signifikan). Hasil tersebut menunjukkan SIPD merupakan partial mediation dalam 
penelitian ini, sehingga $\mathrm{H}_{7}$ yang menyatakan SIPD mampu memediasi pengaruh penyusunan ABK terhadap transparasi anggaran di BPKAD Provinsi Bali dapat diterima. Temuan ini bermakna terlaksananya penyusunan $\mathrm{ABK}$ menandakan baiknya kualitas SDM dan akan mengoptimalkan penerapan SIPD, sehingga transparansi anggaran dapat terwujud di BPAKD Provinsi Bali. Hasil penelitian ini mendukung hasil yang ditemukan oleh Adiwirya \& Sudana (2015) dan Upabayu et al., (2015) bahwa penyusunan ABK berpengaruh positif dan signifikan terhadap transparansi anggaran melalui SIPD. Pengimplementasian anggaran berbasis kinerja akan mendukung merealisasikan transparansi kehadapan masyarakat. Sistem Informasi Pemerintah Daerah (SIPD) diharapkan dapat memberikan dukungan yang kuat melalui tercapainya penyusunan anggaran berbasis kinerja pemerintah daerah yang baik dengan tujuan akhir memberikan pelayanan terhadap publik dalam bentuk transparansi.

\section{SIMPULAN}

Penelitian ini memberikan kesimpulan bahwa secara simultan aksesibilitas, sistem pengendalian internal, dan penyusunan anggaran berbasis kinerja berpengaruh positif pada SIPD. Dikaji secara parsial, ditemukan bahwa SIPD mampu menjadi pemediasi aksesibilitas, sistem pengendalian internal, dan penyusunan anggaran berbasis kinerja terhadap transparansi APBD. Temuan ini menunjukkan bahwa Sistem Informasi Pemerintahan Daerah (SIPD) mempunyai impresi peranan yang penting dalam proses transparansi APBD.

Sebagai bahan masukan dan pertimbangan untuk BPKAD Provinsi Bali maka dapat disarankan untuk lebih memperhatikan aksesibilitas, pengendalian internal, serta penyusunan anggaran berbasis kinerja demi terwujudnya transparansi APBD. Aksesibilitas dapat ditingkatkan dengan menyediakan laporan keuangan yang mudah didapatkan dan dimengerti masyarakat selaku warga negara. Sistem pengendalian internal dapat ditingkatkan dengan memperkuat komitmen pimpinan dan staf, juga konsisten dalam melakukan refreshing serta pelatihan secara mendalam terhadap staf. Penyusunan anggaran berbasis kinerja diharapkan tetap berpedoman pada peraturan-peraturan terbaru terkait keuangan daerah, memperhatikan visi dan misi daerah sejak tahap perencanaan, implementasinya, serta tingkat evaluasi agar tepat sasaran demi terwujudnya cita-cita daerah. Sistem Informasi Pemerintahan Daerah dapat ditingkatkan dengan memaksimalkan fitur-fitur yang terdapat didalamnya dan juga didukung dengan ketersediaan jaringan yang baik di BPKAD Provinsi Bali. Salah satu keterbatasan pada penelitian ini adalah penelitian hanya dilaksanakan di BPKAD Provinsi Bali. Para peneliti yang mengambil tema transparansi APBD dapat memperluas sampel, yaitu dengan menambah sampel pada intansi-intansi lain pada sub bidang yang mengelola keuangan dan non keuangan, maupun mahasiswa selaku publik sehingga data yang diperoleh bisa lebih beragam.

\section{REFERENSI}

Adiwirya, M. F., \& Sudana, I. (2015). Akuntabilitas, Transparansi, Dan Anggaran Berbasis Kinerja Pada Satuan Kerja Perangkat Daerah Kota Denpasar. EJurnal Akuntansi, 11(2), 611-628.

Al-Dmour, A. (2018). The Impact Of The Reliability Of The Accounting 
Information System Upon The Business Performance Via The Mediating Role Of The Quality Of Financial Reporting. The International Journal of Accounting and Business Society, 24(2), 92-112. https://doi.org/10.21776/ub.ijabs.2018.26.1.5

Aminah, S., Maisyarah, N. D., \& AlParok. (2020). Regional Financial Information Systems Effect on Sarolangun Local Government Financial Transparency and Accountability of Financial Report. 125(33), 35-42. https://doi.org/10.2991/aebmr.k.200305.178

Anggayana, I Putu Novan; Wirajaya, I. G. A. (2019). Pengaruh Prinsip-Prinsip Good Governance Dan Budaya Organisasi Terhadap Kinerja Keuangan Lembaga Perkreditan Desa Kota Denpasar. E-Jurnal Akuntansi, 29(1), 325-341.

Aryani, N. K. D., \& Muliati, N. K. (2020). Hita Akuntansi dan Keuangan Universitas Hindu Indonesia Edisi Oktober 2020. Hita Akuntansi Dan Keuangan Universitas Hindu Indonesia, April, 699-730.

Avec, E., \& Dandelot, M. (2018). Evolution and stakes of the right of access to administrative documents since the "Law of 7 October 2016 for a digital republic." Revue Francaise d'Administration Publique, 165(1), 127-133. https://doi.org/10.3917/rfap.165.0127

Aziz, K., Essa, F., Azeez, S., \& Frolova, I. (2020). Institutional Control as an Entry Point for Transparency in Information Disclosure : Field Study in a Sample of Iraqi Banks. 13(11), 958-977.

Ciplet, D., Adams, K. M., Weikmans, R., \& Roberts, J. T. (2018). The Transformative Capability of Transparency in Global Environmental Governance. Global Environmental Politics, 18(3), 46-64. https:/ / doi.org/10.1162/glep_a_00472

Fazny, A. O., \& Setiyawati, H. (2019). The Effect of Implementation of the Internal Control System and the Implementation of Good Corporate Governance Principles on the Quality of Financial Reports (Case Study at Amanah Insani Islamic Community Financing Bank). International Journal of Science and Research (IJSR), 8(5), 12.

Fuadah, H., \& Setiyawati, H. (2020). The Effect of the Implementation of Transparency and Accounting Information Systems on the Quality of Financial Reports. IJO-International Journal of Business ..., 3(11), 1-12. http://www.ijojournals.com/index.php/bm/article/view/371

Hehanussa, S. J. (2015). kutip 1 (Salomi J. Hehanussa ). Conference in Busniess, Accounting and Management, 2, 82-90.

Kurniawati, M. M. H. (2016). Pengaruh Penyajian Laporan Keuangan Daerah, Aksesibilitas Laporan Keuangan Daerah, Dan Sistem Akuntansi Keuangan Daerah Terhadap Transparansi Dan Akuntabilitas Pengelolaan Keuangan Daerah (Studi Pada Satuan Kerja Perangkat Daerah Kabupaten Jember). Jurnal Akuntansi Fakultas Ekonomi Universitas Bung Hata, 8 (2), 15-27.

Majelis Utama Desa Pakraman (MUDP) Bali. (2014). Pararem Lembaga Perkreditan Desa (LPD) Bali.

Maryanti, R. (2017). Pengaruh Teknologi Informasi Dan Sistem Pengendalian Intern Terhadap Efektivitas Sistem Informasi Akuntansi. Akutansi, Audit Dan Sistem Informasi Akutansi (Jasa), 1(1), 40-59.

Medina, C., \& Rufín, R. (2013). Transforming Government: People , Process and Policy Article information: Transforming Government: People, Process and 
Policy, 7(2), 240-255.

Mulyadi, A., Syamsidar, S., \& Efendy, D. (2018). Pengaruh Sistem Pelaporan dan Kejelasan Sasaran Anggaran Terhadap Akuntanbilitas Kinerja Instansi Pemerintah (Studi Pada Satuan Kerja Pemerintah Aceh). Jurnal Riset Inspirasi Manajemen Dan Kewirausahaan, 2(2), 95-101. https://doi.org/10.35130/jrimk.v2i2.21

Nanda, R., \& Darwanis. (2016). Analisis Implementasi Anggaran Berbasis Kinerja Pada Pemerintah Daerah (Studi Deskriptif Pada Dinas DPKKD Kabupaten Aceh Selatan). Jurnal Ilmiah Mahasiswa Ekonomi Akuntansi (JIMEKA), 1(1), 327340.

Peraturan Menteri Dalam Negeri Republik Indonesia Nomor 70 Tahun 2019 Tentang Sistem Informasi Pemerintahan Daerah, (2019).

Peraturan Pemerintah Republik Indonesia Nomor 12 Tahun 2019 Tentang Pengelolaan Keuangan Daerah, (2019).

Prabowo, T. J. W., Leung, P., \& Guthrie, J. (2017). Reforms in public sector accounting and budgeting in Indonesia (2003-2015): Confusions in implementation. Journal of Public Budgeting, Accounting and Financial Management, 29(1), 104-137. https://doi.org/10.1108/jpbafm-29-01-2017b005

Rashedi, H., \& Dargahi, T. (2019). How Influence the Accounting Information Systems Quality of Internal Control On Financial Reporting Quality. Journal of Modern Developments in Management and Accounting Available Online at Www.Jmdma.Ir JMDMA, 2(5), 33-45. www.jmdma.ir

Rohaedi, A., \& Sabaruddinsah, S. (2013). Pengaruh Penyajian Laporan Keuangan Daerah Dan Aksesibilitas Laporan Keuangan Daerah Terhadap Penggunaan Sistem Informasi Pengelolaan Keuangan Daerah. JRAK: Jurnal Riset Akuntansi $\mathcal{E}$ Komputerisasi Akuntansi, 4(02). https:// doi.org/10.33558/jrak.v4i2.1335

Safkaur, O., Afiah, N. N., Poulus, S., \& Dahlan, M. (2019). the Effect of Quality Financial Reporting on Good Governance. International Journal of Economics and Financial Issues, 9(3), 277-286. https:/ / doi.org/10.32479/ijefi.8047

Sari, M. F. (2017). Analisis Penerapan Prinsip Akuntabilitas Dan Transparansi Pengelolaan Keuangan Pada Lembaga Swadaya Masyarakat (LSM) Algheins Kabupaten Ponorogo.

Sugiyono. (2017). Metode Penelitian Kuantitatif, Kualitatif, dan RED. Alfabeta, CV.

Tresyani, T. (2019). Pengaruh Sistem Pengendalian Internal Terhadap Kualitas Sistem Informasi Akuntansi Yang Berdampak Pada Kualitas Informasi Akuntansi (Survei Pada Satuan Kerja Perangkat Daerah Kota Bandung). Akuntansi.

Undang-Undang Republik Indonesia Nomor 14 Tahun 2008 Tentang Keterbukaan Informasi Publik. (2008).

Untary, N. R. (2015). Pengaruh Sistem Informasi Akuntansi, Sistem Pengendalian Intern dan Kompetensi Sumber Daya Manusia terhadap Kualitas Laporan Keuangan Daerah dengan Faktor Eksternal sebagai Pemoderasi (Studi Kasus Pada Pemerintah Daerah Kabupaten Magelang). Diponegoro Journal Of Accounting, Volume 4(2015).

Upabayu, I. P., Mahaputra, R., \& Putra, I. W. (2015). Analisis Faktor-Faktor Yang Mempengaruhi Kualitas Informasi Laporan Keuangan Pemerintah Daerah. 
Jurnal Dinamika Akuntansi, $\quad$ 7(2), 139-149. https://doi.org/10.15294/jda.v7i2.4124

Vilone, L. (2020). Good governance and transparency. Giuristi: Revista de Derecho Corporativo, 1(2), 343-353. https:// doi.org/10.46631/giuristi.2020.v1n2.07

Vita, I. N. M., Dwija, P. I. A., Sadha, S. I. M., \& Ary, W. I. G. (2018). The Effect Of Good Corporate Governance And Tri Hita Karana Culture On The Quality Of Financial Reporting. Russian Journal of Agricultural and Socio-Economic Sciences, 6(June), 496-504.

Wahyuni, S. (2020). Pengaruh Penyajian Laporan Keuangan Daerah dan Aksesibilitas Laporan Keuangan Daerah terhadap Transparansi Pengelolaan Keuangan Daerah (Studi Pada Aceh Singkil). Unmuha.

WAHYUNI, S. (2020). Pengaruh Penyajian Laporan Keuangan Daerah Dan Aksesibilitas Laporan Keuangan Daerah Terhadap Transparansi Pengelolaan Keuangan Daerah (Studi Kasus Pada Pemerintah Kabupaten Aceh Singkil). Universitas Muhammadiyah Aceh.

Wasistiono, S. (2003). Kapita Selekta Penyelenggaraan Pemerintahan Daerah. Fokusmedia.

Wismaningtyas, T. A., \& Kurniasih, Y. (2021). Analisis Ketercapaian Implementasi Undang-Undang Keterbukaan Informasi Publik di Pemerintah Kota Semarang (Studi Kasus: Organisasi Perangkat Daerah dan Pejabat Pengelola Informasi dan Dokumentasi Kota Semarang). Journal of Public Administration and Local Governance, 5(1), 33-42. https:// doi.org/10.31002/jpalg.v5i1.3850 